\title{
4 \\ MAQASIDI JURNAL SYARIAH DAN HUKUM
}

\section{Volume 1, No. 1, Juni 2021}

PARADIGMA HAK ASASI MANUSIA DALAM UNIVERSAL DECLARATION OF HUMAN RIGHTS DAN ISLAM.

Asy'ari

PANDANGAN TOKOH AGAMA TENTANG HARTA HIBAH YANG DIANGGAP SEBAGAI HARTA WARIS DALAM PERSPEKTIF HUKUM ISLAM

Mia Kartika; Idaul Hasanah; Soni Zakaria

TINJAUAN UMUM PUTUSAN HAKIM DAN PERBANDINGAN PEMBUNUHAN YANG TIDAK DISENGAJA ANTARA KUHP DAN HUKUM ISLAM

\section{Ida Rahma}

ANALISIS YURIDIS PUTUSAN MAHKAMAH SYAR'IYAH TAPAKTUAN:

Studi Kasus Nomor Perkara: 24/Pdt.G/2021/MS.Ttn

\section{H. Harnides; Erha Saufan Hadana}

PEMAHAMAN MASYARAKAT TENTANG MUDHARABAH (QIRADH), HIWALAH, DAN SYIRKAH DALAM ISLAM

\section{Fedry Saputra; Amar Maulana}

TINJAUAN HUKUM ISLAM TERHADAP IMPLEMENTASI RESTORATIVE JUSTICE DALAM SISTEM PERADILAN PIDANA ANAK DI INDONESIA

Syaibatul Hamdi; M. Ikhwan; Iskandar 


\title{
SUSUNAN PENGURUS \\ MAQASIDI: JURNAL SYARIAH DAN HUKUM
}

\author{
Penanggung Jawab \\ Adi Kasman
}

\section{Editor In Chief}

Syaibatul Hamdi

\author{
Editor \\ M. Ikhwan \\ Sumardi Efendi \\ Benni Erick \\ Layout \\ Ranto Mulya
}

\begin{abstract}
ALAMAT REDAKSI
J1. Lingkar Kampus Alue Penyareng Gampong Gunong Kleng Kecamatan Meureubo Kabupaten Aceh Barat - Indonesia Telp. 0655 - 7551591 Fax. 0655 - 7551591 email : maqasidi@staindirundeng.ac.id www.ejournal.staindirundeng.ac.id/index.php/maqasidi
\end{abstract}




\title{
Pemahaman Masyarakat Tentang Mudharabah (Qiradh), Hiwalah, Dan Syirkah Dalam Islam
}

\author{
Fedry Saputra dan Amar Maulana \\ STAIN Teungku Dirundeng Meulaboh, Indonesia \\ Email konfirmasi: fedrysaputra@yahoo.co.id
}

\begin{abstract}
ABSTRAK
Penerapan ekonomi syariah di Indonesia dewasa ini semakin marak dan semakin dikenal oleh masyarakat. Ekonomi syariah merupakan alternatif yang dapat dipilih oleh masyarakat yang menginginkan setiap muamalah yang dilakukan bebas dari unsur-unsur yang dilarang agama Islam. Umat Islam di Indonesia sudah semakin menyadari bahwa urusan bermuamalah khususnya dalam bidang ekonomi juga ada aturan-aturan serta rambu-rambu yang harus dipatuhi demi keselamatan dunia dan akherat.Maka dalam bermuamalah, umat Islam berusaha menggunakan akad-akad yang diperbolehkan menurut aturan agama Islam. Qiradh bisa juga di sebut Mudharabah termasuk salah satu bentu akad syirkah (perkongsian). Hiwalah ini merupakan system yang unik yang sesuai untuk di adaptasikan kepda manusia. Hal ini karena hiwalah sangat erat hubungannya dengan kehidupan manusia. Hiwalah sering berlaku dalam permasalahan hutang piutang. Syirkah adalah kerja sama antara dua orang atau lebih dalam berusaha, yang keuntungan dan kerugiannya di tanggung bersama.
\end{abstract}

Kata kunci: Mudharabah (Qiradh); Hiwalah; dan Syirkah.

\section{Pendahuluan}

Indonesia bunga bank masih menjadi polemik tersendiri karena para ulama masih belum sepakat tentang boleh-tidaknya sehingga dalam praktek, baik perbankan syariah maupun perbankan konvensional berjalan bersama-sama (Edwin Nasution, 294: 2007). Perbedaan pendapat ini diklasifikasikan menjadi tiga pandangan, yaitu: pertama, bunga bank adalah termasuk dalam kategori riba sehingga hukumnya haram, sedikit atau banyak unsur; kedua, bunga bank bukan termasuk dalam kategori riba sehingga halal untuk dilakukan; ketiga, riba termasuk dalam klasifikasi mutasyabihat sehingga sebaiknya bunga bank tidak dilakukan (Muslimin H. Kara, 80: 2005).

Hikmah diharamkannya riba antara lain: pertama, riba dapat menimbulkan sikap permusuhan antar individu dan juga menghilangkan tolong-menolong sesama manusia; kedua, riba menumbuhkan mental boros dan malas yang mau mendapatkan harta tanpa kerja keras, menjadi benalu yang tumbuh di atas jerih payah orang lain; ketiga, riba adalah salah satu bentuk penjajahan; dan keempat, 
Islam mengajak manusia agar mendermakan kepada saudaranya yang membutuhkan. Alasan lain pelarangan riba antara lain: pertama, riba tak lain adalah perampasan hak milik orang lain tanpa ada nilai imbangan; kedua, riba dilarang karena menghalangi orang dari keikutsertaan dalam profesi-profesi aktif; ketiga, perjanjian riba menimbulkan hubungan yang tegang antara sesama manusia; keempat, perjanjian riba adalah alat yang digunakan orang kaya untuk mendapatkan kelebihan dari modal dan ini bertentangan dengan keadilan dan persamaan; dan kelima, keharaman riba dinyatakan oleh nas Al-Qurean dan manusia tidak harus mengetahui alasannya.

Masyarakat sejak dahulu tidak terlepas dari proses jual-beli dan kerjasama dalam bidang perekonomian. Dalam ilmu fiqh terdapat macam-macam kerjasama dalam perekonomian yang memang penting untuk di pelajari untuk kemaslahatan masyarakat atau umat. Dan apabila akan ada beberapa orang yang akan berserikat dalam kerjasama ini, maka tergantung ingin bekerjasama dengan cara yang diinginkan dan sesuai dengan kemampuan individu masing-masing dan ketentuanketentuannya.

Terdapat beberapa bentuk kerjasama dan jasa dalam pandangan Islam, yaitu kerjasama yang pertama yaitu syirkah, yang kedua yaitu mudharabah atau qiradh, yang ketiga yaitu hiwalah. Untuk mengetahui kejelasan dari bentuk-bentuk atau macam-macam kerjasama diatas maka diperlukan kajian yang seksama. Untuk itu, ingin memaparkan beberapa penjelasan dari ulama-ulama fiqh mengenai akad-akad yang digunakan dalam jual beli dan kerjasama tersebut.

\section{Metode Penelitian}

Metode dalam penulisanini menggunakan penelitian deskriptif, yaitu dengan cara mengumpulkan berbagai informasi atau data yang didapat dengan membandingkan pendapat para ahli yang berhubungan dengan permasalahan yang diteliti secara deskriptif analisis.

\section{Pembahasan/hasil}

\section{Mudharabah atau Qiradh}

a. Definis Mudharabah atau Qiradh

Lafazh "Qiradh" menurut bahasa adalah berasal dari lafazh "Qardlu” artinya Ialah "memutus". Sedangkan menurut syara' ialah satu akad penyerahan harta yang dilakukan oleh pemiliknya kepada seseorang supaya memperdagangkan harta tersebut dan keuntungannya dibagi berdua.

Qiradh berasal dari kata qaradha yang berarti "memutuskan atau memastikan". Di namakan qiradh karena pemilik uang memutuskan atau memastikan untuk menyerahkan sebagian uangnya kepada orang lain untuk di perdagangkan, dan juga memutuskan untuk membagi labanya. Definisi qiradh 
menurut syara' adalah akad penyerahan kepada orang lain untuk di pedagangkan, kemudian labanya dibagi menurut syarat-syarat yang di tentukan, baik di bagi sama rata maupun tidak sama antara pemilik uang dan pengusaha yang memperdagangkan uang tersebut.

Qiradh bisa juga di sebut Mudharabah termasuk salah satu bentu akad syirkah (perkongsian). Istilah Mudharabah di gunakan oleh orang Irak, sedangkan orang Hijaz menyebutnya dengan istilah Qiradh. Dengan demikian, mudharabah dan qiradh adalah dua istilah yang sama. Orang Irak menyebutnya dengan istilah mudharabah sebab, setiap orang yang melakukan akad memiliki bagian dari laba. Atau pengusaha harus mengadakan perjalanan dalam mengusahakan harta modal tersebut (Al Imam Taqiyuddin Abubakar Alhusaini, 2011).

b. Dasar Hukum Mudharabah atau Qiradh

Dasar hukum qiradh di perbolehkan, kerena qiradh adalah apa yang di lakukan oleh Rasulullah saw ketika beliau berakad qiradh dengan siti khadijah (sebelum nikah) untuk memperdagangkan hartanya ke negara syam dan lain-lain. Para sahabat juga telah sepakat menetapkan sah nya perdagangan seperti itu.

Ada yang mengkiyaskan qiradh dengan mushaqah (akad pengairan tanaman), karena sama-sama dibutuhkan oleh masyarakat. Sebab kadang-kadang seseorang itu mempunyai sawah ladang dan pembiayaan, namun tidak mempunyai keahlian dalam menggolahnya, sedangkan orang lain tidak mempunyai sawah atau ladang, ada yang mempunyai keahlian untuk mengolah sawah atau ladang tersebut.

Akad qiradh itu sesuai dengan hadist riwayat Ibnu Majah, bahwa Rasulullah SAW pernah bersabda :

Artinya: "Ada tiga hal yang mengandung berkah, yaitu jual-beli, yang diberi tempo (masa khiar), penyerahan (pinjaman) uang untuk diperdagangkan, dan campuran gandum dengan terigu bukan untuk di jual-belikan.(H.R Ibnu Majah)".

1) Syarat dan Rukun Mudharabah atau Qiradh

Adapun rukun dan syarat mudharabah atau qiradh yaitu (Sulaiman Rasyid, 299: 2012:

a) Harta (modal), baik berupa uang ataupun lainnya.Syaratnya keadaan modal hendaknya di ketahui banyaknya oleh kedua belah pihak ketika modal tersebut diserahkan.

b) Pekerjaan, yaitu berdagang dan lain-lainnya yang berhubungan dengan urusan perdagangan tersebut. Syaratnya Barang yang hendak di perdagangkan, begitu juga tempat, hendaknya tidak ditentukan, hanya di serahkan saja pada pekerja harus dijelaskan secara rinci ketika dalam akad.

c) Keuntungan, Syaratnya banyaknya keuntungan untuk bekerja hendaklah di tentukan sewaktu akad, misalnya seperdua atau sepertiga dari jumlah keuntungan. 
d) Yang punya modal dan yang bekerja (pekerja). Syaratnya Keduanya hendaklah orang yang berakal dan sudah baligh (berumur 15 tahun) dan bukan orang yang di paksa.

e) Sighat ( ijab kabul)

2) Macam - Macam Qiradh

Qiradh ada dua macam, yaitu qiradh mutlak (al-mutlaq) dan qiradg terikat (almuqayyad). Qiradh mutlak adalah penyerahan modal seseorang kepada pengusaha tanpa memberikan batasan, seperti berkata "saya serahkan uang ini kepada mu untuk diusahakan, sedangkan labanya akan dibagi di antara kita, masing-masing setengah atau sepertiga, dan lain-lain".

Qiradh muqayyad (terikat) adalah penyerahan modal seseorang kepada pengusaha dengan memberikan batasan. Seperti persayratan bahwa pengusaha harus berdagang di daerah bandung atau harus berdagang sepatu, atau membeli barang dari orang tertentu, dan lain-lain.

Ulama Hanafiyah dan Imam Ahmad memperbolehkan memberi batasan dengan waktu dan orang, tetapi ulama Syafi'iyah dan Malikiyah melarangnya. Ulama' Hanafiyah dan Ahmad pun membolehkan akad apabila dikaitkan dengan masa yang akan dating, seperti, "Usahakan modal ini mulai bulan depan," sedangkan ulama' Syafi'iyah dan Malikiyah melarangnya (Rachmat Syafei, 227: 1997).

3) Cara Pelaksanaanya

Karena orang yang bekerja wajib ikhlas dalam segala urusan yang bersangkutan dengan qiradl, hendaklah ia dibenarkan dengan semua sumpahnya apabila ia mengatakan tidak mendapat keuntungan atau hanya memperoleh sedikit keuntungan. Begitu juga banyak dan sedikitnya modal, atau dia mengatakan bahwa modalnya hilang, semua pengakuan tersebut hendaklah diperkuat dengan sumpahnya.

Kalau orang yang bekerja dan yang punya modal berselisih tentang pembagian keuntungan, umpamanya orang yang bekerja mengatakan untuk dia seperdua, sedangkan yang punya modal sepertiga, kedua-duanya hendaklah besumpah, dan orang yang bekerja itu di beri keuntungan menurut kebiasaan yang berlaku di tempat dan waktu itu.

Akad qirad adalah akad saling percaya. Maka apabila ada barang yang hilang, yang bekerja tidak wajib mengganti, kecuali jika karena kelalaiannya. Kerugian hendaklah ditutupi (diganti) dengan keuntungan. Kalau masih juga rugi, kerugian itu hendaklah dipikul oleh yang punyamodal sendiri, berarti yang bekerja tidak dituntut mengganti kerugian (Sulaiman Rasyid, 300: 2012).

\section{b. Hiwalah}

1. Definisi Hiwalah

Kata hawalah dengan dibaca fathah huruf ha' dan dibaca kasrah, menurut bahasa arinya mengalihkan. Sedangkan menurut syara' ialah memindahkan hak dari 
tanggungannya orang yang mengalihkan kepada oarang yang dilimpahi tanggungan. Kata Hiwalah menurut bahasa berarti pindah/beralih. Menurut istilah, artinya adalah pengalihan utang-piutang dari tanggungan seseorang menjadi tanggungan orang lain. Sebenarnya Hiwalah itu merupakan penukaran suatu piutang dengan piutang yang lain, menurut kaul yang ashah. Namun, tidak di kategorikan dalam masalah jual beli karena kebutuhan masyarakat sangat mendesak.

Menurut bahasa, Hiwalah artinya "mengalihkan". Sedangkan menurut syara' ialah memindahkan hak dari tanggungannya orang yang mengalihkan kepada orang yang di limpahi tanggungan.

Hiwalah ialah memindahkan utang dari tanggungan seseorang kepada tanggungan orang lain. Hiwalah ini merupakan system yang unik yang sesuai untuk di adaptasikan kepda manusia. Hal ini karena hiwalah sangat erat hubungan nya dengan kehidupan manusia. Hiwalah sering berlaku dalam permasalahan hutang piutang. Maka salah satu cara untuk menyelesaikan masalah hutang piutang dalam muamalah adalah hiwalah. Hiwalah bukan saja di gunakan untuk menyelesaikan masalah hutang piutang akan tetapi bisa juga digunakan sebagai pemindah dana dari individu kepada individu yang lain (Asy Syekh bin Qosim AlGhazy Muhammad, 375: 1991).

2. Dasar Hukum Hiwalah

Dasar di pebolehkannya Hiwalah adalah ijmak ulama dan hadist nabi Muhammad SAW yang di riwayatkan Imam Bukhori dan Imam Muslim bahwa Nabi Muhammad SAW bersabda:

Artinya: "Penundaan pembayaran oleh orang kaya adalah suatu kedzaliman (penganiayaan), apabila utang seseorang terhadap orang kaya di alihkan menjadi tanggunganmu, maka turutlah!" (H.R. bukhori dan Muslim)

Dalam riwayat lain, hadist tersebut berbunyi sebagai berikut :

Artinya: "... apabila utang seseorang terhadap orang kaya dialihkan menjadi tanggunganmu, maka terimalah pengalihan utang itu." (H.R. Ahmad dan Baihaqi)

3. Rukun dan Syarat Hiwalah (Alhusaini, 89 - 92: 2011)

a) Rukun Hiwalah

- Muhil (orang yang berhutang dan berpiutang).

- Muhtal (orang yang berpiutang).

- Muhal alaih (orang yang berutang).

- Utang muhil kapada muhtal.

- Utang muhal alaih kepada muhil

- Sigat (lafaz akad) 
b) Syarat Hiwalah

- Kerelaan Muhil. Adapun Muhil ialah orang yang mempunyai tanggungan hutang. Tidak disyaratkan atas orang yang dibebani pemindahan hutang, karena sesungguhnya memang tidak ada syarat kerelaan orang yang dibebani pemindahan hutang (Muhal 'alaihi) menurut pendapat yang lebih shaleh. Dan tidak boleh akad Hiwalah atas orang yang tidak mempunyai hutang.

- Adanya qabul oleh Muhtal. Adapun Muhtal ialah orang yang hak piutangnya dipindahkan atas Muhil (orang yang mempunyai tanggungan hutang).

- Hak yang dipindahkan itu tetap berada dalam tanggungan. Adapun memberikan qayyid dengan kata "tetap" adalah sesuai dengan pendapat yang dikemukakan oleh Imam Rafi'i tetapi Imam Nawawi didalam kitab Raudlah telah menyusuli pendapat tersebut bahwa yang di tetapkan sebagai hutang adalah yang ada dalam pemindahan itu saja, atau hutang yang baru akan menjadi tanggungan.

- Adanya penyesuaian tanggungan hutang si Muhil (orang yang mempunyai tanggungan hutang) dan Muhal 'alaih (orang yang dibebani pemindahan hutang) dalam hal jenis perkiraannya, macamnya, kontan atau tempo dan masih utuh atau sudah pecah.

4. Macam - Macam Hiwalah

Madzhab Hanafiyah membagi Hiwalah kepada 2 macam, yaitu (Sulaiman Rasyid, 214: 2012):

a) Al-hiwalah al-Muqayyadah (Pemindahan Bersyarat)

Yaitu pemindahan sebagai ganti dari pembayaran utang dari pihak pertama kepada pihak kedua.

Contoh: Samkhun berpiutang kepada Isman sebesar satu juta rupiah, sedangkan Isman juga berpiutang pada Fahmi satu juta rupiah. Isman kemudian memindahkan haknya untuk menagih piutangnya yang terdapat pada Fahmi kepada Samkhun.

b) Al-hiwalah al-Muthlaqah (Pemindahan Mutlak)

Yaitu pemindahan yang tidak di tegaskan sebagai ganti pembayaran utang pihak pertama kepada pihak kedua.

Contoh; Isman berhutang kepada samkhun sebesar satu juta rupiah. Karena Fahmi juga berhutang kepada Isman sebesar satu juta rupiah. Isman mengalihkan utangnya kepada Fahmi sehingga Fahmi berkewajiban membayar utang Isman kepada Samkhun, tanpa menyebutkan bahwa pemindahan utang itu sebagai ganti utang Fahmi kepada Isman. 


\section{Cara Pelaksaanaanya}

Umpamanya A (muhil) berhutang kepada B (muhtal) dan ia (A) berpiutang kepada C (muhal alaih). Jadi, A adalah orang yang berutang dan berpiutang, B hanya berpiutang, dan $\mathrm{C}$ hanya berutang. Kemudian A dengan persetujuan $\mathrm{B}$ menyuruh $C$ membayar utangnya kepada $B$, tidak kepada (A); setelah terjadi akad hiwalah, terlepaslah A dari utangnya kepada B dan $\mathrm{C}$ tidak berutng lagi kepada $\mathrm{A}$, tetapi utangnya kepada A telah berpindah kepada B; berarti $C$ harus membayar utangnya itu kepada B, tidak lagi kepada A.

Memindahkan utang dengan cara ini tidak ada halangannya, dengan syarat "keadaan C mampu membayar utangnya, dan dengan ridha kedua-nya (A dan B)"( Sulaiman Rasyid, 312 - 313: 2012).

\section{c. Syirkah}

1. Definisi Syirkah

Syirkah menurut bahasa berarti al-ikhtilah yang artinya campur atau pencampuran. Demikian dinyatakan oleh Taqiyadun. Maksud pencampuran disini ialah seseprang mencampurkan hartanya dengan harta orang lain sehingga tidak mungkin untuk dibedakan.

Menurut istilah, yang dimaksud dengan syirkah, para fuqaha berbeda pendapat sebagai berikut:

a) Sayyid Sabiq

b) Akad antara dua orang berserikat pada pokok harta (modal) dan keuntungan.

c) Muhammad al-Syarbini al-Khatib

d) Ketetapan hak pada sesuatu untuk dua orang atau lebih dengan cara yang masyhur (diketahui).

e) Syihab al-Din al-Qalyubi wa Umaira

f) Penetapan hak pada sesuatu bagi dua orang atau lebih.

g) Idris Ahmad

h) Syirkah sama dengan syarikat dagang, yakni dua orang atau lebih sama-sama berjanji dan akan bekerja sama dalam dagang, dengan menyerahkan modal masing-masing, dimana keuntungan dan kerugiannya diperhitungkan menurut besar kecilnya modal masing-masing.

Setelah diketahui definisi syirkah menurut para ulama, kiranya dapat dipahami bahwa yang dimaksud dengan syirkah adalah kerja sama antara dua orang atau lebih dalam berusaha, yang keuntungan dan kerugiannya di tanggung bersama (Hendi Suhendi, 125: 2010).

2. Dasar Hukum

a. Al-Qur'an

Dalam Q.S. Shad ayat 24 
Artinya: "sesungguhnya kebanyakan dari orang-orang yang berserikat itu sebagian mereka berbuat zalim kepada sebagian yang lain, kecuali orang-orang yang beriman dan beramal soleh dan amat sedikitlah mereka ini".

b. As-Sunah

Adapun yang dijadikan dasar hukum syirkah oleh para ulama adalah sebuah hadis yang diriwayatkan Abu Dawud dari Abi Hurairah dari Nabi Muhammad SAW bersabda : "aku jadi ketiga antara dua orang yang berserikat selama yang satu tidak berkhianat kepada yang lainnya, apabila yang satu berkhianat, kepada pihak yang lain maka keluarlah aku drinya".

c. Ijma'

Umat Islam sepakat bahwa syirkah dibolehkan. Hanya saja, mereka berbeda pendapat tentang jenisnya ((Hendi Suhendi, 125: 2010).

3. Rukun dan Syarat

a. Rukunnya

1). Pihak yang berakad

2). Harta atau barang

3). Ijab kabul

Rukun syirkah diperselisihkan oleh para ulama, menurut ulama Hanafiyah bahwa rukun syirkah ada dua, yaitu ijab dan kabul sebab ijab kabul (akad) yang menentukan adanya syirkah. Adapun yang lain seperti dua orang atau pihak yang berakad dan harta berada diluar pembahasan akad seperti terdahulu dalam akad jual beli.

b. Syarat

Syarat-syarat yang berhubungan dengan syirkah menurut Hanafiyah menjadi empat bagian berikut ini :

1) Sesuatu yang bertalian dengan semua bentuk syirksh baik dengan harta maupun yang lainnya. Dalam hal ini terdapat dua syarat, yaitu a) yang berkenaan dengan benda diakadkan adalah harus dapat diterima sebagai perwakilan, b) yang berkenaan dengan keuntungan, yaitu pembagian keuntungan harus jelas dan dapat diketahui dua pihak.

2) Sesuatu yang bertalian dengan syirkah mal (harta), ada dua perkara yaitu, yaitu a) bahwa modal yang dijadikan ojek adalah dari alat pembayaran, seperyi riyal, dan rupiyah, b) yang dijadikan modal ada ketika akad syirkah dilakukan.

3) Sesuatu yang bertalian dengan syirkah mufawadhah, bahwa disyaratkan a) modal harus sama, b) bagi yang dijadikan objek akad disyaratkan syirkah umum, yakni pada semua macam jual beli atau perdagangan.

4) Adapun yang bertalian dengan syirkah inan sama dengan syarat syirkah mufawadhah. 
Menurut Malikiyah syarat-syarat yang bertalian dengan orang yang melakukan akad ialah merdeka, baligh dan pintar.

Syafiiyah berpendapat bahwa syirkah yang sah hukumnya hanyalah syirkah inan, sedangkan syirkah yang lainnya batal. Dijelaskan pula oleh Abd. Al-Rahman al-Jaziri bahwa rukun syirkah adalah dua orang yang berserikat sighat dan objek akad syirkah baik harta maupun kerja.

\section{Macam - Macam Syirkah}

Syirkah ada dua jenis (Adiwarman Kaarim, 36: 2004):

a. Pertama: Syirkah Amlaak (Hak Milik)

Yaitu penguasaan harta secara kolektif, berupa bangunan, barang bergerak atau barang berharga. Yaitu perserikatan dua orang atau lebih yang dimiliki melalui transaksi jual beli, hadiah, warisan atau yang lainnya. Dalam bentuk syirkah seperti ini kedua belah pihak tidak berhak mengusik bagian rekan kongsinya, ia tidak boleh menggunakannya tanpa seijin rekannya.

Misalnya; si A dan si B diberi wasiat atau hadiah berupa sebuah mobil oleh seseorang dan keduanya menerimanya, atau membelinya dengan uang keduanya, atau mendapatkannya dari hasil warisan, maka mereka berdua berserikat dalam kepemilikan mobil tersebut.

b. Kedua : Syirkah Uquud (Transaksional/kontrak)

Yaitu akad kerja sama antara dua orang yang bersekutu dalam modal dan keuntungan, misalnya, dalam transaksi jual beli atau lainnya. Bentuk syirkah seperti inilah yang hendak kami bahas dalam tulisan kali ini. Dalam syirkah seperti ini, pihak-pihak yang berkongsi berhak menggunakan barang syirkah dengan kuasa masing-masing. Dalam hal ini, seseorang bertindak sebagai pemilik barang, jika yang digunakan adalah miliknya. Dan sebagai wakil, jika barang yang dipergunakan adalah milik rekannya. Macam-Macam Syirkah Uquud (Transaksional/kontrak):

1) Syirkah al-'Inaan,

Yaitu kerja sama antara dua orang atau lebih dengan harta masing-masing untuk dikelola oleh mereka sendiri, dan keuntungan dibagi di antara mereka, atau salah seorang sebagai pengelola dan mendapat jatah keuntungan lebih banyak daripada rekannya. Jenis syirkah ini yang sering dilakukan oleh kebanyakan orang, karena tidak disyaratkan adanya kesamaan modal, usaha dan tanggung jawab.

Contoh syirkah inân: A dan B pengrajin atau tukang kayu. A dan B sepakat menjalankan bisnis dengan memproduksi dan menjualbelikan meubel. Masing-masing memberikan konstribusi modal sebesar Rp.50 juta dan keduanya sama-sama bekerja dalam syirkah tersebut. Dalam syirkah ini, disyaratkan modalnya harus berupa uang (nuqûd); sedangkan barang ('urûdh), misalnya rumah atau mobil, tidak boleh dijadikan modal syirkah, 
kecuali jika barang itu dihitung nilainya pada saat akad. Keuntungan didasarkan pada kesepakatan, sedangkan kerugian ditanggung oleh masing-masing mitra usaha (syarîk) berdasarkan porsi modal. Jika, misalnya, masing-masing modalnya 50\%, maka masing-masing menanggung kerugian sebesar 50\%. sebagaimana kaidah fikih yang berlaku, yakni (Ar-Ribhu 'Alâ mâ Syarathâ wal Wadhii'atu 'Alâ Qadril Mâlain).

2) Syirkah al-Mudharabah,

Yaitu, seseorang sebagai pemodal (investor) menyerahkan sejumlah modal kepada pihak pengelola (mudharib) untuk diperdagangkan, dan dia berhak mendapat prosentase tertentu dari keuntungan.

3) Syirkah al-Wujuuh,

Yaitu kerja sama antara dua orang atau lebih yang memiliki reputasi dan nama baik serta ahli dalam bisnis. Mereka membeli barang secara kredit (hutang) dari suatu perusahaan dan menjual barang tersebut secara tunai, lalu keuntungan yang didapat dibagi bersama atas dasar kesepakatan di antara mereka. Syirkah semacam ini juga dibolehkan menurut kalangan hanafiyah dan hanbaliyah, namun tidak sah menurut kalangan Malikiyah, Syafi'iyah dan Zhahiriyah. Disebut syirkah wujûh karena didasarkan pada kedudukan, ketokohan, atau keahlian seseorang di tengah masyarakat. Tak seorang pun memiliki modal, namun mereka memiliki nama baik, sehingga mereka membeli barang secara hutang dengan jaminan nama baik tersebut. Contohnya: A dan B adalah tokoh yang dipercaya pedagang. Lalu A dan B ber-syirkah wujûh, dengan cara membeli barang dari seorang pedagang (misalnya C) secara kredit. A dan B bersepakat, masing-masing memiliki $50 \%$ dari barang yang dibeli. Lalu keduanya menjual barang tersebut dan keuntungannya dibagi dua, sedangkan harga pokoknya dikembalikan kepada C (pedagang).

c. Syirkah al-Abdaan (syirkah usaha),

Yaitu kerja sama antaradua orang atau lebih dalam usaha yang dilakukan oleh tubuh mereka, yakni masing-masing hanya memberikan konstribusi kerja ('amal), tanpa konstribusi modal (mâl), seperti kerja sama sesame dokter di klinik, atau sesama arsitek untuk menggarap sebuah proyek, atau kerja sama dua orang penjahit untuk menerima order pembuatan seragam sekolah. Dalam syirkah ini tidak disyaratkan kesamaan profesi atau keahlian, tetapi boleh berbeda profesi. Jadi, boleh saja syirkah 'abdan terdiri dari beberapa tukang kayu dan tukang besi. Keuntungan yang diperoleh dibagi berdasarkan kesepakatan; nisbahnya boleh sama dan boleh juga tidak sama di antara mitra-mitra usaha (syarîk).

Contohnya: A dan B. keduanya adalah nelayan, bersepakat melaut bersama untuk mencari ikan. Mereka sepakat pula, jika memperoleh ikan dan dijual, 
hasilnya akan dibagi dengan ketentuan: A mendapatkan sebesar $60 \%$ dan B sebesar $40 \%$.

d. Syirkah al-Mufawadhah,

Yaitu kerja sama antara dua orang atau lebih. Setiap pihak memberikan suatu porsi dari keseluruhan dana dan berpartisipasi dalam kerja. Setiap pihak membagi keuntungan dan kerugian secara sama.

\section{Kesimpulan}

Qiradh berasal dari kata qaradha yang berarti "memutuskan atau memastikan". Di namakan qiradh karena pemilik uang memutuskan atau memastikan untuk menyerahkan sebagian uangnya kepada orang lain untuk di perdagangkan, dan juga memutuskan untuk membagi labanya. Definisi qiradh menurut syara' adalah akad penyerahan kepada orang lain untuk di pedagangkan, kemudian labanya dibagi menurut syarat-syarat yang di tentukan, baik di bagi sama rata maupun tidak sama antara pemilik uang dan pengusaha yang memperdagangkan uang tersebut. Qiradh bisa juga di sebut Mudharabah termasuk salah satu bentu akad syirkah (perkongsian). Istilah Mudharabah di gunakan oleh orang Irak, sedangkan orang Hijaz menyebutnya dengan istilah Qiradh. Dengan demikian, mudharabah dan qiradh adalah dua istilah yang sama. Orang Irak menyebutnya dengan istilah mudharabah sebab, setiap orang yang melakukan akad memiliki bagian dari laba. Atau pengusaha harus mengadakan perjalanan dalam mengusahakan harta modal tersebut.

Hiwalah ialah memindahkan utang dari tanggungan seseorang kepada tanggungan orang lain. Hiwalah ini merupakan system yang unik yang sesuai untuk di adaptasikan kepda manusia. Hal ini karena hiwalah sangat erat hubungan nya dengan kehidupan manusia. Hiwalah sering berlaku dalam permasalahan hutang piutang. Maka salah satu cara untuk menyelesaikan masalah hutang piutang dalam muamalah adalah hiwalah. Hiwalah bukan saja di gunakan untuk menyelesaikan masalah hutang piutang akan tetapi bisa juga digunakan sebagai pemindah dana dari individu kepada individu yang lain.

syirkah adalah kerja sama antara dua orang atau lebih dalam berusaha, yang keuntungan dan kerugiannya di tanggung bersama.

\section{DAFTAR PUSTAKA}

Karim, Adiwarman. 2004. Bank Islam Analisis Fiqh dan Keuangan, Jakarta : Raja Grafindo Persada.

Al-Ghazy, Asy Syekh Muhammad bin Qosim. 1991. Fathul Qorib Jilid 1, Surabaya, Alhusaini. 2011. Kifayatul Akhyar, Surabaya : Bina Ilmu.

Edwin, Nasution. 2007. Pengenalan Eksklusif Ekonomi Islam, Jakarta: Kencana Prenada Media Group. 
Kara, Muslimin H. (2005) Bank Syariah di Indonesia: Analisis Kebijakan Pemerintah Indonesia Tentang Perbankan Syariah, Yogyakarta: UII Press.

Rasyid, Sulaiman. 2012. Fiqh Islam, Bandung: Sinar Baru Algensindo.

Syafei, Rachmat. 1997, Fiqh Muamalah, Bandung: Gunung Jati Press.

Hendi, Suhendi. 2010. Fiqh Muamalah, Jakarta : Rajawali Press.

Al Imam, Taqiyuddin Abubakar Alhusaini. 2011. Kifayatuk Akhyar, Surabaya : PT Bina Ilmu. 